Boletín de la Sociedad Geológica Mexicana

VOLUMEN 65, NÚM. 2, 2013, P. 225-233

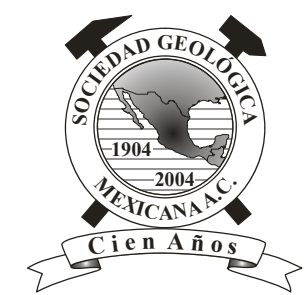

\title{
Miocene brachyuran Crustacea from Konar-Takhteh and Ahram sections, southwestern Iran
}

\author{
Mehdi Yazdi ${ }^{1}$, Ali Bahrami ${ }^{1}$, Peyman Abbasi ${ }^{1}$, Reza Sadeghi², Francisco J. Vega, \\ ${ }^{1}$ Department of Geology, University of Isfahan, POB. 81746-73441, Isfahan, I.R. Iran. \\ ${ }^{2}$ Payamnoor University, Department of Geology, I. R. Iran. \\ ${ }^{3}$ Instituto de Geología, UNAM, Ciudad Universitaria, Coyoacán, México, D.F., 04510, México. \\ *vegver@unam.mx
}

\begin{abstract}
Five species of brachyuran Crustacea from the Middle Miocene are described from the Guri Member of the Mishan Formation in southwestern Iran. The species include the leucosioids Leucosia persica; Seulosia sp. cf. S. rhomboidalis; Myra sp.; the portunoid Portunus withersi and the xanthid Demania ahramensis n. sp. The paleobiogeographic affinities of these genera reinforce previous interpretations of a wide distribution between the Persian Gulf and the Indopacific regions.
\end{abstract}

Keywords: Crustacea, Decapoda, Brachyura, Miocene, southwestern Iran.

\section{Resumen}

Se describen cinco especies de crustáceos braquiuros del Mioceno Medio del Miembro Guri de la Formación Mishan en el suroeste

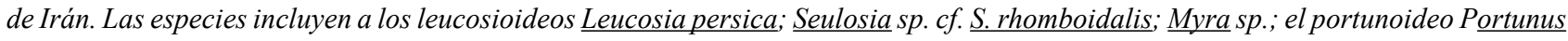
withersi y el xántido Demania ahramensis $n$. sp. Las afinidades paleobiogeográficas de éstos géneros refuerzan las interpretaciones previas sobre una amplia distribución entre las regiones del Golfo Pérsico y el Indopacífico.

Palabras Clave: Crustacea, Decapoda, Brachyura, Mioceno, suroeste de Irán.

\section{Introduction}

After the Burdigalian (Early Miocene) lake depositional system of Gachsaran Formation (on the depression of areas between Fars platform and Dezful expression), marine environments expanded and the Gachsaran Formation was covered by a transgressive and shallow marine sequence (the Mishan Formation). The Mishan Formation contains about $943 \mathrm{~m}$ of green to grey marl and clay-limestone with rich fossil content. The lower $60 \mathrm{~m}$ of this formation consist of burrowed limestone, which is replaced by reef limestone, called the "Guri member" of Mishan Formation (Fig. 1). In the type section (Gachsaran oil field), its name is derived from a village (Mishan village) located in $50 \mathrm{~km}$ south - southeast of Gachsaran city at Southwestern Iran (Figs. 2, 3). The Mishan Formation is mainly sandy at the type section area and changes laterally to siltstone facies at inner Fars and Bandar Abbas regions.

In other regions, except for inner Fars in which Mishan Formation is located over the Razak Formation, the Mishan Formation overlies the Gachsaran Formation and is overlaid by the Aghajari Formation. The lower boundary is sharp and the upper boundary transitional. Reef limestone from Guri Member of Mishan Formation is an index due to its large content of Operculina and other micofossils. In addition to plankton foraminifera, bivalves, gastropods, echinoids and 


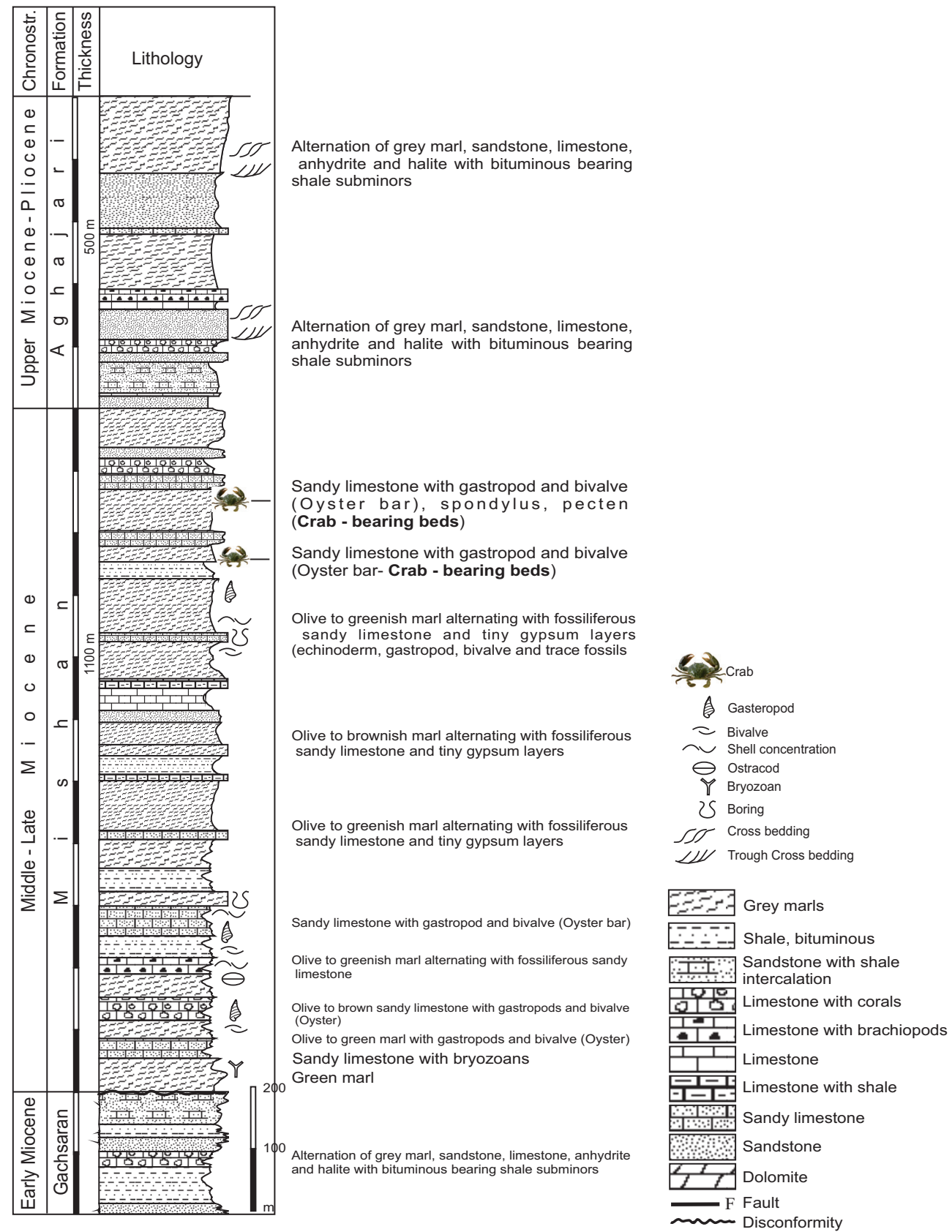

Figure 1. Composed stratigraphic column at Konar Takhteh and Ahram sections, Southern Iran, with position of crustacean-bearing horizons of the Mishan Formation.

crustaceans, it suggest an early to Middle Miocene age for this formation. Two sandy limestone horizons at the upper part of Mishan Formation (studied in Konar-Takhteh and Ahram sections) bear rich and diverse crustaceans fossils (Fig. 3).

All the studied specimens are housed at the University of Isfahan, Department of Geology under acronym EUIC. The museum number of each specimen is given at the figure caption.

The Miocene deposits of southwestern Iran are rich in crustacean remains. Vega et al. (2012) listed 13 species, most of them belonging to extant genera which are mainly distributed today in the Indopacific region. The paleobiogeographic affinities of the Miocene brachyuran fauna from Iran with the Indopacific region were mentioned by Glaessner (1933), Vega et al. (2010, 2012) and Heidari et al. (2012). The Guri Member of the Mishan Formation is probably one of the most productive lithostratigraphic units in terms of diversity and abundance of Miocene crustaceans. Future collects will surely reveal that the Mishan Formation has a fossil crustacean diversity as high as that reported from Miocene to Pleistocene lithostratigraphic units of the 


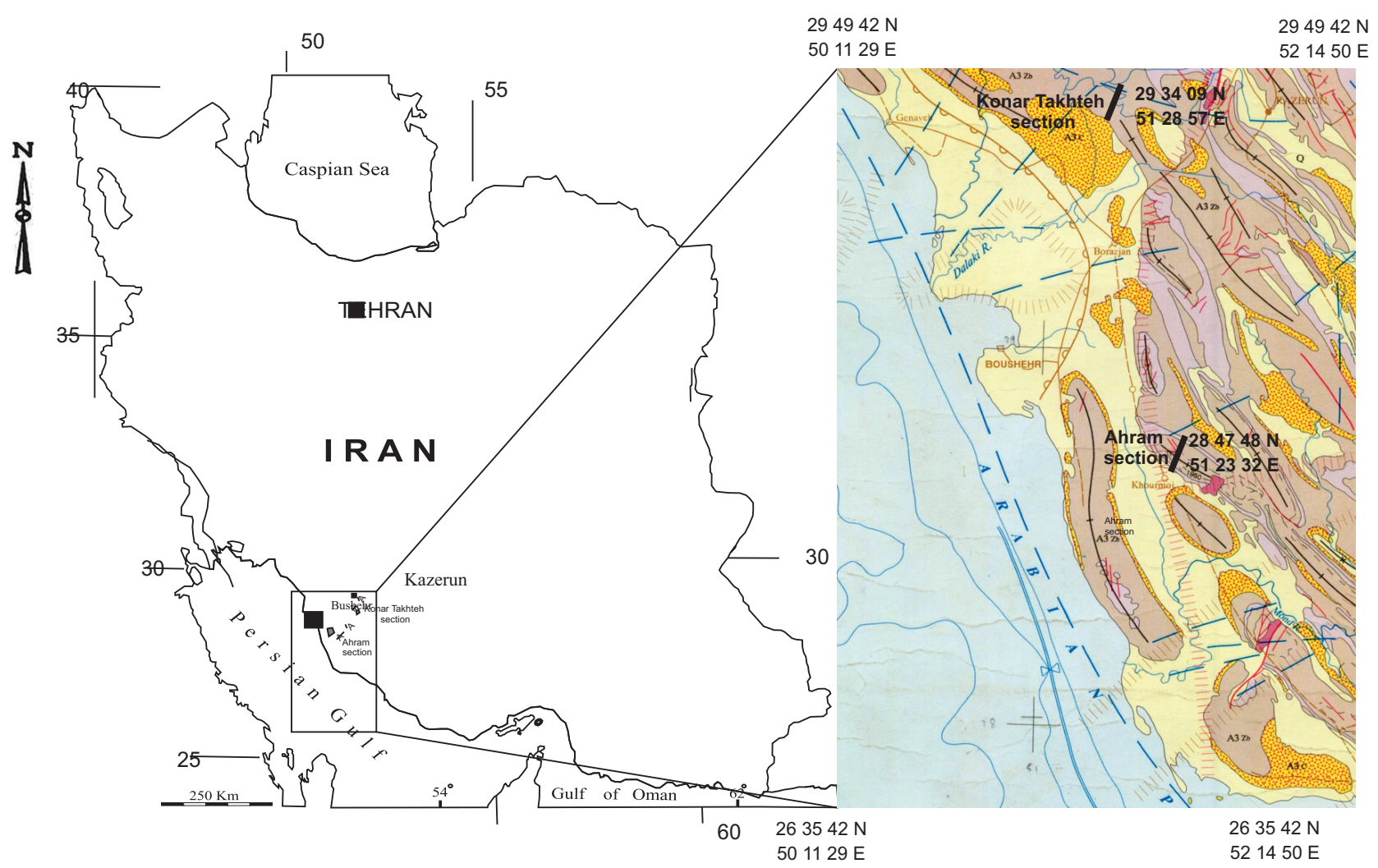

Figure 2. Location map of the Konar Takhteh and Ahram sections, Southern Iran.

Indopacific region (see Karasawa et al., 2008 for examples and references).

\section{Geological setting}

The studied sections are part of Iranian oilfields at the Southwestern portion of the country. Konar-Takhteh section (Fig. 3) is located $10 \mathrm{~km}$ from Konar-Takhteh city, $35 \mathrm{~km}$ southeast of Kazerun, before (Tunnel 2 Pisa) underground

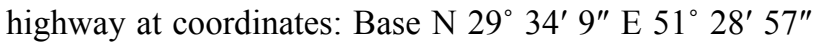
(Fig. 2).

Ahram section is located $15 \mathrm{~km}$ east of Ahram city, close to the Beniun village, $175 \mathrm{~km}$ southeast of Kazerun, with coordinates: Base N $28^{\circ} 47^{\prime} 48^{\prime \prime}$ E $51^{\circ} 23^{\prime} 32^{\prime \prime}$ (Fig.2)

The main lithology of the Mishan Formation in the studied section consists of reef limestones of the Guri Member at the base of the formation and green to grey marls with several sandy limestones, thin layers of gypsum and sub minors of sandstone. Because of the similar lithology and fossil contents between the two studied sections, only one section is here described.

The detailed measured sequence and lithologic features (top to base) of the Mishan Formation at Konar-Takhteh section is as it follows:

- Top: Alternation of fine grained micro-conglomerate, gray marl, sandstone, sandy limestones, anhydrite and halite with bituminous shales, (Aghajari Formation) - $500 \mathrm{~m}$.
- Green marl with thin sandstone layers, sandy limestones intercalations and thin bedded gypsum layers - $100 \mathrm{~m}$.

- Yellow to grey sandy limestones layers rich in gastropods, bivalves and crustaceans (Crab bearing beds) $-20 \mathrm{~m}$.

- Olive to greenish marls with gypsum layers - $80 \mathrm{~m}$.

- Yellow to grey sandy limestones layers rich in gastropods, bivalves and crustaceans (Crab bearing beds) $15 \mathrm{~m}$.

- Platy green marl and sandy brown limestones - $260 \mathrm{~m}$.

- Grey to white thin bedded sandy limestones with bivalves, gastropods and bryozoans - $50 \mathrm{~m}$.

- Olive to green marl with thin bituminous shale layers $-315 \mathrm{~m}$.

- Green marls - 150 m.

- Green to grey marls with sandy brownish limestones and gypsum intercalations $-20 \mathrm{~m}$.

- Base: Red to brown thick bedded gypsum, halite and grey to brown shale (Gachsaran Formation).

\section{Systematic palaeontology}

Infraorder Brachyura Latreille, 1802

Section Eubrachyura de Saint-Laurent, 1980

Superfamily Leucosioidea Samouelle, 1819

Family Leucosiidae Samouelle, 1819

Subfamily Leucosiinae Samouelle, 1819 

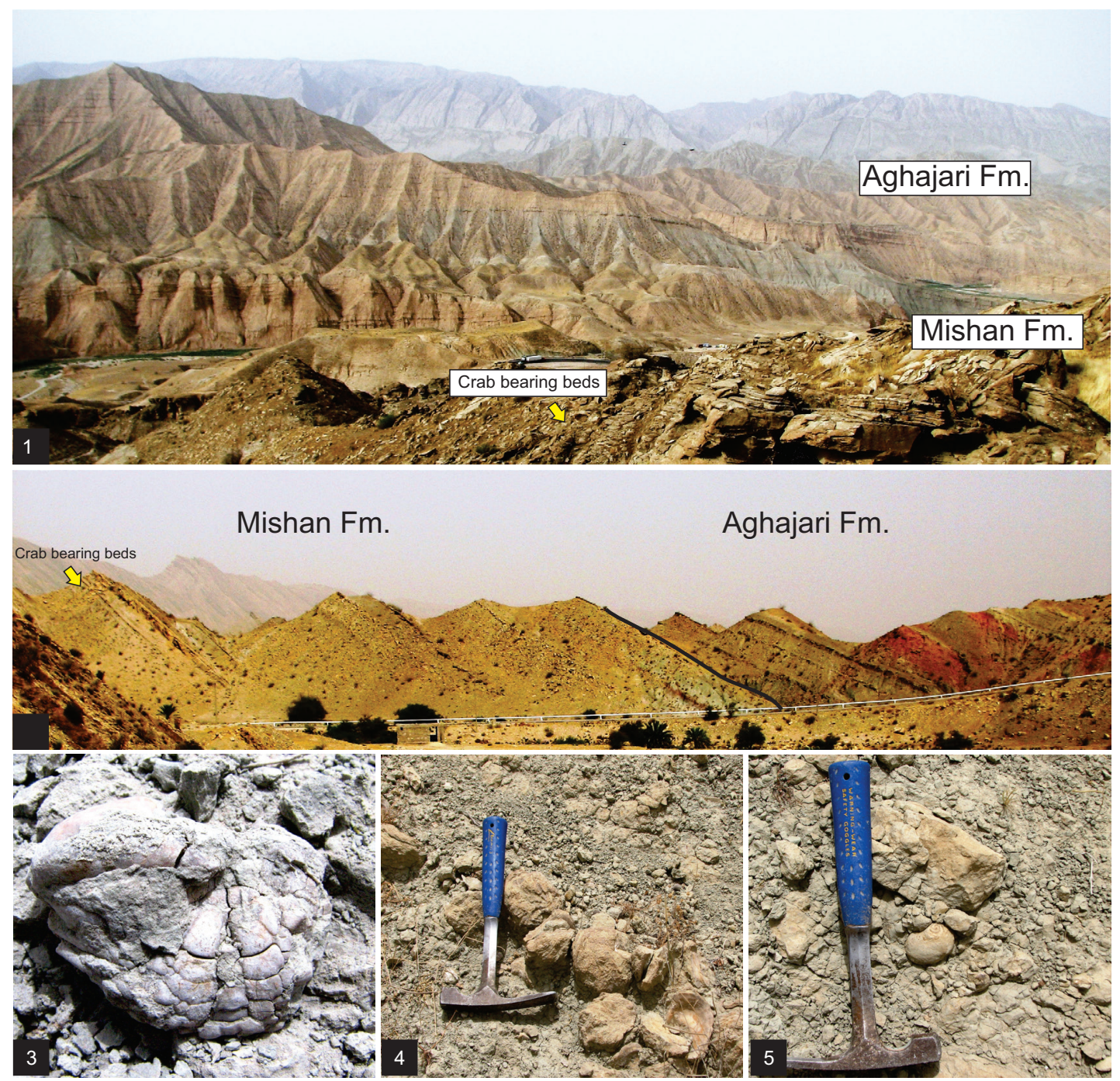

Figure 3. Panoramic view of Gachsaran, Mishan and Agahjari Fms. at Konar-Takhteh section with position of studied horizons.

Genus Leucosia Weber, 1795

Type species: Cancer craniolaris Linnaeus, 1758, by subsequent designation of Holthuis (1959).

Leucosia persica Vega, Gholamalian and Bahrami, 2010 Fig. $4.1-4.11$

Leucosia persica Vega, Gholamalian and Bahrami, 2010, p. 486 , fig. 5 a-p.

Description: see Vega et al. (2010, p. 487).

Material: Seven incomplete carapaces, EUIC $503-$ EUIC 509, Konar-Takhteh section, Middle Miocene Mishan Formation, Iran.

Measurements: EUIC 503, carapace length $=24 \mathrm{~mm}$, width $=20 \mathrm{~mm}$, height $=6 \mathrm{~mm}$; EUIC 504, carapace length $=$ $28 \mathrm{~mm}$, width $=22 \mathrm{~mm}$, height $=6 \mathrm{~mm}$; EUIC 505, carapace length $=24 \mathrm{~mm}$, width $=25 \mathrm{~mm}$, height $=5 \mathrm{~mm}$; EUIC 506, carapace length $=24 \mathrm{~mm}$, width $=23 \mathrm{~mm}$, height $=6 \mathrm{~mm}$; EUIC 507, carapace length $=27 \mathrm{~mm}$, width $=26 \mathrm{~mm}$, height
$=8 \mathrm{~mm}$; EUIC 508, carapace length $=22 \mathrm{~mm}$, width $=17$ $\mathrm{mm}$, height $7=\mathrm{mm}$; EUIC 509, carapace length $=20 \mathrm{~mm}$, width $=21 \mathrm{~mm}$, height $=6 \mathrm{~mm}$.

Discussion: The species was described from the Middle Miocene Mishan Formation of the Hormozgan Province, southern Iran (Vega et al., 2010).

\section{Genus Seulocia Galil, 2005}

Type species: Leucosia rhomboidalis de Haan, 1841, by subsequent designation of Galil (2005).

\section{Seulosia sp. cf. S. rhomboidalis (de Haan, 1841)}

Fig. 4.12, 4.13

Description: Subrhomboidal carapace, constricted front, widest at midlength; anterolateral margin one-third the total carapace length; rimmed posterolateral margin; rounded posterior margin; elongate sternum; subquadrate, fused sternites 3 and 4; sternites 5 constricted on median 


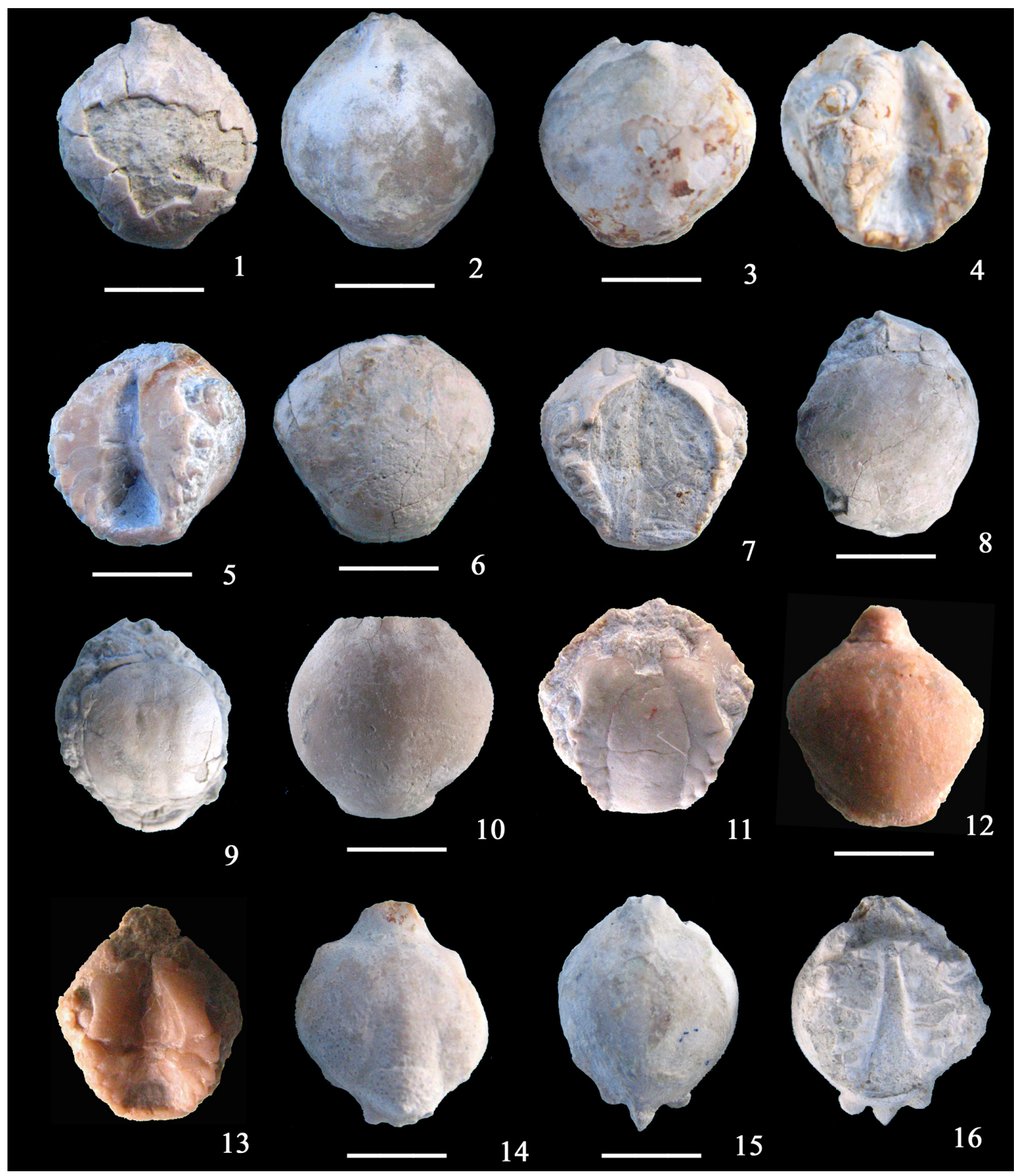

Figure 4. 1 - 11: Leucosia persica Vega, Gholamalian and Bahrami, 2010. 1: Dorsal view of carapace, EUIC 503. 2: Dorsal view of carapace, EUIC 504. 3, 4: Dorsal and ventral view of carapace, EUIC 505. 5: Ventral view of carapace, EUIC 506. 6, 7: Dorsal and ventral view of carapace, EUIC 507. 8, 9: Dorsal and ventral view of female carapace, EUIC 508. 10, 11: Dorsal and ventral view of carapace, EUIC 509. 12, 13: Seulosia sp. cf. S. rhomboidalis (de Haan, 1841), Dorsal and ventral view of carapace, EUIC 510. 14 - 16: Myra sp. 14: Dorsal view of carapace, EUIC 511. 15, 16: Dorsal and ventral view of carapace, EUIC 518. Scale bars $=1 \mathrm{~cm}$.

portion; subovate sternites 6 , postero-laterally inclined; subovate sternites 7 and 8 similar.

Material: One incomplete carapace, EUIC 510, Ahram section, Middle Miocene Mishan Formation, Iran.

Measurements: EUIC 510, carapace length $=14 \mathrm{~mm}$, width $=10 \mathrm{~mm}$, height $=4 \mathrm{~mm}$.

Discussion: Seulocia rhomboidalis is an extant species, with a fossil record from the Pliocene-Pleistocene of Taiwan
(Hu and Tao, 1996). The single Iranian specimen is similar to this species, but more complete specimens are needed to confirm the specific identity.

\section{Subfamily Ebaliinae Stimpson, 1871 \\ Genus Myra Leach, 1817}

Type species: Leucosia fugax Fabricius, 1798, by monotypy. 
Myra sp.

Fig. $4.14-4.16$

Description: Subovate carapace, constricted anteriorly, wider at anterior third, surface covered by fine granules; narrow anterior margin; sinuous anterolateral margin; posterolateral margin broadly curved; narrow posterior margin, about one-fourth the maximum carapace level, with short, rounded posterolateral tubercles; posterior spine relatively short, twice the length of anterolateral tubercles; sternum subovate longitudinally; subtrapezoidal, fused sternites 3 and 4 ; sinuous sternites 5 to 7 , decreasing progressively in size towards posterior portion.

Material: Two incomplete carapaces, EUIC 511 and EUIC 518, Konar-Takhteh section, Middle Miocene Mishan Formation, Iran.

Measurements: EUIC 511, carapace length $=15 \mathrm{~mm}$, width $=14 \mathrm{~mm}$, height $=6 \mathrm{~mm}$; EUIC 518, carapace length $=13 \mathrm{~mm}$, width $=12 \mathrm{~mm}$, height $=5 \mathrm{~mm}$.

Discussion: The Iranian specimens differ from Myra gurii Vega, Gholamalian, Hassani, Sajadi and Schaaf, 2012 (also from the Middle Miocene Mishan Formation), in having a much constricted anterior carapace region, granulose dorsal carapace surface, much shorter posterior spine and deeper grooves separating branchial from cardiac and intestinal areas. More complete specimens are needed to confirm a possible new species.

Superfamily Portunoidea Rafinesque, 1815 Family Portunidae Rafinesque, 1815

Genus Portunus Weber, 1795

Type species: Cancer pelagicus Linnaeus, 1758, by subsequent designation of Rathbun (1926).

Portunus withersi (Glaessner, 1933)

Fig. $5.1-5.4$

Neptunus (Achelous) withersi Glaessner, 1933, p. 8, pl. 2, figs. 1-3.

Portunus (Achelous) withersi (Glaessner, 1933); Glaessner, 1969, p. R510, fig. 319.2.

Portunus withersi (Glaessner, 1933); Karasawa et al., 2008, p. 127.

Portunus withersi (Glaessner, 1933); Heidari et al., 2012, p. 3, fig. 5.

Description: Carapace one-third wider than long; curved anterolateral margin, with at least five antero-lateral spines of uniform size; slightly curved posterolateral margin, smooth, about two-thirds the total carapace length; posterior margin nearly straight, smooth, half the maximum carapace width; dorsal carapace regions not clearly marked; broad branchial areas; relatively deep cervical groove; distinct gastrocardiac and lateral cardiac grooves; relatively wide third maxillipeds, with median longitudinal groove; elongate sternum, fused, triangular sternites 1 and 2, inverted triangular sternite 3 , inverted subtrapezoidal sternite 4 , with median longitudinal deep groove and lateral process, subrectangular sternites 5 , with rounded outer margins, twothirds the length of sternite 4 , sternites 6 nearly identical to sternites 5 , sternites 7 one-third longer than sternites 6 , sternites 8 small, subtriangular, one-third shorter and narrower than sternites 7; triangular male pleon, triangular telson, one-third longer than sternites 5, subtrapezoidal, fused somites 5-6, one-third shorter than length of sternites 6 and 7 together, trapezoidal, fused somites 3-4, base nearly as wide as posterior margin, one-third longer than somite 6; wide third maxillipeds with median longitudinal groove.

Material: Three incomplete carapaces, EUIC 512 and EUIC 513, Konar-Takhteh section, Middle Miocene Mishan Formation, Iran.

Measurements: EUIC 512, carapace length $=53 \mathrm{~mm}$, width $=64 \mathrm{~mm}$, height $=12 \mathrm{~mm}$; EUIC 513, carapace length $=55 \mathrm{~mm}$, width $=67 \mathrm{~mm}$, height $=12 \mathrm{~mm}$; EUIC 519 , carapace length $=50 \mathrm{~mm}$, width $=61 \mathrm{~mm}$, height $=11 \mathrm{~mm}$.

Discussion: The species has been reported from the Lower Miocene of Iran by Glaessner (1933), from the Fars Group near Sulabadar and the Guri Member of the Mishan Formation at Hormozgan, Southern Iran (Heidari et al., 2012). This report extends the biostratigraphic record of the species to the Middle Miocene.

\section{Family Xanthidae MacLeay, 1838, sensu Karasawa and Schweitzer, 2006 \\ Subfamily Xanthinae MacLeay, 1838 \\ Genus Demania Laurie, 1906}

Type species: Demania splendida Laurie, 1906, by original designation.

\section{Demania ahramensis $\mathrm{n} . \mathrm{sp}$.}

Fig. $5.5-5.10$

Diagnosis: Subhexagonal carapace, widest at midlength; fronto-orbital margin half the maximum carapace width; narrow orbits, with two notches on dorsal surface; anterolateral margin with three lobes; strongest lobe at mid-length; smooth posterolateral margin; straight posterior margin; dorsal carapace regions and cervical groove well defined; elongate sternum; triangular male pleon; chelipeds relatively massive, equal; elongate, slender P2-P4.

Description: Subhexagonal carapace, one-third wider than long, widest at mid-length; fronto-orbital margin half the maximum carapace width; anteriorly protruded front, bilobed; narrow orbits, with two notches on dorsal surface; convex anterolateral margin, with three lobes that become stronger towards posterior portion; strongest lobe at mid-length; convex posterolateral margin, nearly as long as anterolateral margin, without lobes; straight posterior margin, half the maximum carapace width; well defined dorsal carapace regions; inverted subtriangular potogastric lobes; clearly marked mesogastric process, extends to level of orbits; subpentagonal mesogastric region; subquadrate cardiac region; depressed intestinal region; 


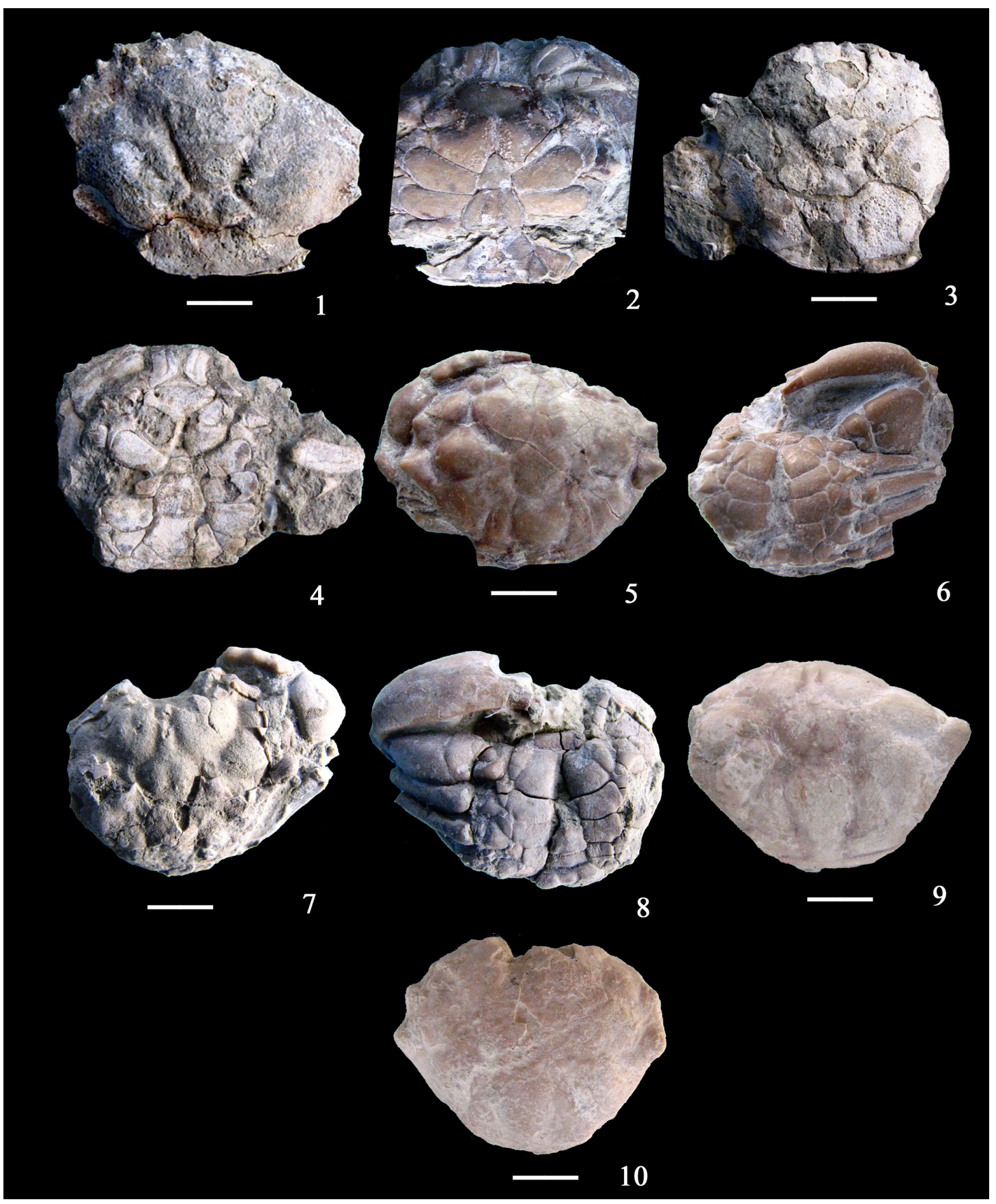

Fig. 5.1 - 4: Portunus withersi (Glaessner, 1933). 1, 2: Dorsal and ventral view of male carapace, EUIC 512. 2, 3: Dorsal and ventral view of male carapace, EUIC 513. 5 - 10: Demania ahramensis n. sp. 5, 6: Dorsal and ventral view of male carapace, holotype EUIC 514. 7, 8: Dorsal and ventral view of male carapace, paratype EUIC 515. 9: Dorsal view of carapace, paratype EUIC 516. 10: Dorsal view of carapace, paratype EUIC 517. Scale bars = $1 \mathrm{~cm}$.

transversely ovate hepatic lobes; transversely subovate, elevated mesobranchial regions; flat metabranchial regions; elongate sternum; transversely subovate sternite 3 ; inverted subtrapezoidal sternite 4, with lateral process; subrectangular sternites 5 , as wide but one-third shorter than sternite 4, with lateral process; subquadrate sternites 6 , one-third longer than sternites 5, with lateral process; sternites 7 subquadrate, as long but half the width of sternites 6; triangular male pleon, triangular telson, one-third longer than sternites 5, subtrapezoidal; somite 6, one-third shorter than length of sternites 6 and 7 together; subrectangular somite 5 , half the length of somite 6 ; rectangular somite 4 , one third wider but slightly shorter than somite 5; equal, massive chelipeds; subrectangular coxa of right cheliped, two-thirds the length of sternite 4; small basis, subtriangular; subrectangular ischium, one-third wider than coxa; subrectangular merus, massive, three times the length of ischium; massive carpus, subquadrate, half the 
length of merus; subrectangular palm, with a row of three tubercles on dorsal surface; articles of left cheliped nearly identical to those of right cheliped, except for merus that is more massive; subrectangular coxae of P2-P4; basis small; subquadrate ischia; elongate, subrectangular meri.

Etymology: The specific name is derived from the Ahram section, Southern Iran.

Material: Four carapaces, two of them nearly complete, EUIC 514 - EUIC 517, Konar-Takhteh section, Middle Miocene Mishan Formation, Iran.

Measurements: Holotype EUIC 514, carapace length $=30 \mathrm{~mm}$, width $=44 \mathrm{~mm}$, height $=15 \mathrm{~mm}$; paratype EUIC 515 , carapace length $=30 \mathrm{~mm}$, width $=42 \mathrm{~mm}$, height $=15$ $\mathrm{mm}$; paratype EUIC 516, carapace length $=28 \mathrm{~mm}$, width $=30 \mathrm{~mm}$, height $=18 \mathrm{~mm}$; paratype EUIC 517, carapace length $=40 \mathrm{~mm}$, width $=45 \mathrm{~mm}$, height $=18 \mathrm{~mm}$.

Discussion: The fossil record of the extant genus Demania includes Demania caltripes (Alcock, 1898) from the Pliocene-Pleistocene of Taiwan (Hu and Tao, 1996); D. chayiensis $(\mathrm{Hu}, 1981)$ from the Late Miocene to Early Pliocene of Taiwan (Hu, 1981; Hu and Tao,1996); D. pilipinas Karasawa and Kato, 2008 (in Karasawa et al., 2008) from the Early Pleistocene of the Mandog Formation, Phillipines (Karasawa et al., 2008); D. reynaudi (H. Milne Edwards, 1834) from the Pliocene-Pleistocene of Taiwan (Hu and Tao, 1996); D. scamberrima (Walker, 1887) from the Pliocene of Java (Van Straelen, 1938); D. wardi Garth and $\mathrm{Ng}, 1985$, from the Pleistocene of New Hebrides (Garth and $\mathrm{Ng}, 1985$ ) and Demania sp. from the Early Pleistocene of the Mandog Formation, Phillipines (Karasawa et al., 2008).

The new species differs from the other fossil species of Demania in having a smooth dorsal carapace surface, while the previously known fossil species have tubercular or granular surfaces. The Iranian species extends the biostratigraphic and paleogeographic range for the genus to the Middle Miocene of the eastern Tethys.

\section{Acknowledgements}

We thank Hiroaki Karasawa and Alessandro Garassino for their kind suggestions to improve the manuscript.

\section{References}

Alcock, A., 1898, Materials for a carcinological fauna of India. No. 3. The Brachyura Cyclometopa. Part 1. The family Xanthidae: Journal of the Asiatic Society of Bengal, 67(1), 67-233.

de Haan, W., 1833-1850, Crustacea, in: von P. F. Siebold, Fauna Japonica sive descriptio animalium, quae in Itinere per Japoniam, Jussu et auspiciis superiorum, qui Summun in India Batava Imperium tenent, suscepto, annis 1823-1830 collegit, notis, observationibus et adumbrationibus illustravit.pp. i-xvii_i-xxxi_ix-xvi_1-243, pls. A-J L-Q 1-55. Ludguni-Batavorum.

Fabricius, J.C., 1798, Supplementatione Entomologiae Systematicae: i-iv, 1-572. (C. G. Proft et Storch, Hafniae [=Copenhagen]).
Galil, B.S., 2005, Contributions to the knowledge of Leucosidae IV, Seulocia gen nov. (Crustacea: Brachyura): Zoologische Mededelingen, Leiden 79(2), 41-59.

Garth, J.S., Ng, P.K.L., 1985, Notes on the genus Demania Laurie, 1906 (Crustacea, Decapoda, Brachyura, Xanthidae): Indo-Malayan Zoology, 2, 293-308.

Glaessner, M.F., 1933, New Tertiary crabs in the collection of the British Museum: Annals and Magazine of Natural History, 10, 12, 1-28.

Glaessner, M.F., 1969, Decapoda, pp. R400-R533, R626-R628, in: Moore, R.C. (ed.), Treatise on Invertebrate Paleontology, R (4)(2). Geological Society of America, Boulder, Colorado, and University of Kansas Press, Lawrence, Kansas.

Heidari, A., Feldmann, R.M., Moussavi-Harami, R., 2012, Miocene decapod crustacean from the Guri Member of the Mishan Formation, Bandar-Abbas, Southern Iran: Bulletin of the Mizunami Fossil Museum, 38, 1-7.

Holthuis, L.B., 1959, The Crustacea Decapoda of Suriname (Dutch Guiana): Zoologische Verhandelingen, Leiden 44, 1-296.

Hu, C.H., 1981, Studies on Cenozoic fossil crabs from Taiwan Island: Proceedings of the Geological Society of China, 24,56-74.

Hu, C.H., Tao, H.J., 1996, Crustacean fossils of Taiwan, Taipei, 228 p.

Karasawa, H., Schweitzer, C.E., 2006, A new classification of the Xanthoidea sensu lato (Crustacea: Decapoda: Brachyura) based on phylogenetic analysis and traditional systematics and evaluation of all fossil Xanthoidea sensu lato: Contributions to Zoology, 75(1/2), 23-73.

Karasawa, H., Schweitzer, C.E., Feldmann, R.M., 2008, Revision of Portunoidea Rafinesque, 1815 (Decapoda: Brachyura) with emphasis on the fossil genera and families: Journal of Crustacean Biology, $28,82-127$.

Karasawa, H., Kato, H., Kase, T. Maac-Aguilar, Y., Kurihara, Y., Hayashi, H., Hagino, K., 2008, Neogene and quaternary ghost shrimps and crabs (Crustacea: Decapoda) from the Philippines: Bulletin of the National Science Museum, Tokyo, Series C 34, 51-76.

Latreille, P.A., 1802-1803, Histoire naturelle, générale et particuliére des crustacés et des insectes, F. Dufart, Paris, 468 p.

Laurie, R.D., 1906, Report on the Brachyura collected by Professor Herdman, at Ceylon, in 1902, in: Herdman, W.A., Report to the Government of Ceylon on the Pearl Oyster Fisheries of the Gulf of Manaar with supplementary reports upon the Marine Biology of Ceylon by other Naturalists, part 5, suppl. Rep., 40: 349-432.

Leach, W.E., 1817, Monograph on the Genera and Species of the Malacostracous Family Leucosidea, in: Leach, W.E. (ed.) The Zoological Miscellany; being descriptions of new, or interesting animals. Vol. 3. Covent Garden and London: E. Nodder and Son. $17-26$.

Linnaeus, C., 1758, Systema Naturae per Regna Tria Naturae, Secundum Classes, Ordines, Genera, Species, cum Characteribus, Differentiis, Synonymis, Locis, Tomus 1. Laurentii Salvii, Stockholm, 823 p.

MacLeay, W., 1838, On the brachyurous decapod Crustacea brought from the Cape by Dr. Smith in: Illustrations of the Annulosa of South Africa; being a portion of the objects of Natural History chiefly collected during an expedition into the interior of South Africa, under the direction of Dr. Andrew Smith, in the years 1834, 1835, and 1836; Fitted out by "The Cape of Good Hope Association for Exploring Africa", London., pls. 2, 3. 53-71.

Milne Edwards, H., 1834-1837, Histoire naturelle des Crustacés, comprenant l'anatomie, la physiologie et la classification de ces animaux. 1 (1834): 468 p., 2(1837), 532 p., Atlas. Libraire Encyclopédique de Roret, Paris.

Rafinesque, C.S., 1815, Analyse de la nature, ou tableau de l'univers et des corps organisées, L'Imprimerie de Jean Barravecchia, Palermo, $1-224$

Rathbun, M.J., 1926, Brachyuran crabs from Australia and New Guinea: Records of the Australian Museum, 15(2), 177-182.

Saint-Laurent, M. de, 1980, Sur la classification et la phylogénie des Crustacés Décapodes Brachyoures. I. Podotremata Guinot, 1977 et Eubrachyura sect. Nov: Comptes Rendus Hebdomadaires des Séances de l'Académie des Sciences, Paris 290, 1265-1268. 
Samouelle, G., 1819, The entomologist's useful compendium, or an introduction to the knowledge of British insects, London, $486 \mathrm{p}$.

Stimpson, W., 1871, Preliminary report on the Crustacea dredged in the Gulf Stream in the Straits of Florida, by L. F. de Pourtalès, Assist. U.S. Coast Survey. Part I. Brachyura: Bulletin of the Museum of Comparative Zoology, 2(1-5), 109-160.

Van Straelen, V., 1938, Crustacés Décapodes cénozoiques des Indes Orientales Néerlandaises: Leidsche Geologische Mededeelingen, 10(1), 90-103.

Vega, F.J., Gholamalian, H., Bahrami, A., 2010, First record of Miocene crustaceans from Hormozgan Province, Southern Iran: Paläontologische Zeitschrift, 84, 485-493.

Vega, F.J., Gholamalian, H., Hassani, M-J., Sajadi, S-H., Schaaf, P., 2012, Miocene Crustacea from northern Bandar Abbas, South Iran: Neues Jahrbuch fuer Geologie und Palaontologie, 265(3), 221-234.
Walker, A.O., 1887, Notes on a collection of Crustacea from Singapore: Journal of the Linnean Society of London, 20(118), 107-117.

Weber, F., 1795, Nomenclator entomologicus secundum Entomologiam Systematicam ill. Fabricii adjectis speciebus recens detectis et varietatibus, Kiel and Hamburg, 171p.

Manuscript received: February 21, 2013.

Corrected manuscript received: March 20, 2013.

Manuscript accepted: March 21, 2013. 